\title{
Identifications of Character Values from the History of Dokterswoning Cultural Heritage Buildings and Potentials for Learning History Resources in Schools
}

\author{
Kian Amboro', Elis Setiawati², Adi Setiawan ${ }^{3}$, Barnas Rasmana 4 , \\ Pandu Pinuju Widodo 5
}

\author{
${ }^{1}$ Members of the Cultural Heritage Council, Metro City, Lampung, Indonesia \\ ${ }^{2}$ Lecturer in History Education Program, University of Muhammadiyah Metro, Lampung, Indonesia \\ ${ }^{3}$ History Teacher in SMA Negeri 1 Sekampung, Lampung Timur Regency, Lampung, Indonesia \\ ${ }^{4}$ Activist in the Archive, History, and Cultural Heritage Community, Metro City, Lampung, Indonesia \\ ${ }^{5}$ Activist in the Trimoerdjo Heritage Community, Lampung Tengah Regency, Lampung, Indonesia
}

Corresponding Author: Kian Amboro

\begin{abstract}
History learning is full of value, both from past stories that can be used as learning, as well as from the various traces left behind. The traces left by history have now become cultural heritage which has important meaning for human life. In the context of education, this cultural heritage has the potential to be used as a source of historical learning because it has important values and character values that can be developed. One of the cultural heritages found in Metro, Lampung is the Dokterswoning cultural heritage building. This study uses a descriptive qualitative approach with inductive methods, to produce general conclusions. The results showed that 1) Dokterswoning Cultural Heritage Building is a historical building from the era of the Dutch East Indies colonial government, which was built in 1939-1940 and is a residence for government doctors who were given the task of providing health services for colonists in Metro; 2) the important value of Dokterswoning as a source of historical learning lies in the contextual historical aspect and its existence as the guardian of a collective memory; 3) integrating the character values of the Dokterswoning Cultural Heritage Building into historical learning by the values of the national character in the Guidelines for the Development of Cultural Education and National Character and can be implemented according to Core Competencies and Basic Competencies in historical subjects. It is
\end{abstract}

concluded that the history and heritage buildings of Dokterswoning have important values as sources of historical learning as well as some character values that can be developed in historical learning.

Keywords: moral values, character values, cultural heritage buildings, learning resources, history learning, history education

\section{INTRODUCTION}

Value and character education are now being felt as an urgent need in the era of globalization. The progress of world culture which is increasingly materialistic has become a threat to humans as humanistic beings who have been civilized because of their values and characters. Historical education, both as part of social science and as an independent historical subject, is very important and has a high contribution to cultural development and the character of the nation (Hasan, 2012). As a field of science, historical knowledge is reconstructed through historical traces from the past and now becomes historical evidence in the present. The evidence that remains is both material and intangible. Through historical education and historical learning, many historical facts contain messages that can be taken and transformed into values. These values can later be 
developed into characters that need to be familiarized.

The student center approach in learning strongly emphasizes the role of students as learning subjects. Student learning activities are not only related to cognitive processes but also affection which will be related to values. Values and characters in history learning should not only be conveyed by the teacher but involving students in the process of clarifying values so that they become accustomed to character must be carried out by the students themselves as learning subjects. This is where the teacher's role becomes important as a facilitator. The use of various historical evidence as a learning resource will be the teacher's main role in designing the history learning process. Among the many historical evidence that can be used as a source of learning is the existence of cultural heritage that is nearby and in the vicinity.

Law of the Republic of Indonesia Number 11 of 2010 concerning Cultural Heritage, defines cultural heritage as material cultural heritage in the form of Cultural Conservation Objects, Cultural Conservation Buildings, Cultural Conservation Structures, Cultural Heritage Sites, and Cultural Conservation Areas on land and / or in water its existence needs to be preserved because it has important values for history, science, education, religion, and I or culture through the process of stipulation (UU RI No 11, 2010). Meanwhile, UNESCO defines cultural heritage into several specific categories, namely tangible cultural heritage and intangible cultural heritage. Tangible cultural heritage consists of movable cultural heritage such as paintings, sculptures, coins, manuscripts; immovable cultural heritage such as monuments, historical and archaeological sites, etc.; as well as underwater cultural heritage such as shipwrecks, underwater ruins, and cities. Meanwhile, intangible cultural heritage includes oral traditions, performing arts, and traditional rituals (UNESCO, n.d.).
Historical relics that meet the criteria as cultural heritage, such as buildings, monuments, sites, are very easy to identify and use for educational purposes because of their tangible nature.

In connection with the explanation above, Metro as an area that has historical records since the colonial period has some cultural heritage remains one of which is the Dokterswoning cultural heritage building. Physically and historically, Dokterswoning's existence can be used as a source of historical learning. Rohani argues that learning resources are all kinds that are outside the student whose existence facilitates the learning process (Rohani, 1997). Therefore, whatever is around students has the potential to be used as a source of learning. Ariyani et al. suggest that the potential of learning resources is anything that can be used for learning, references in learning resources are not only in the form of textbooks, but can be in the form of places and equipment in the surrounding environment (Ariyani \& Huda, 2016). Meanwhile, the Association of Education and Communication Technology (AECT) explains that the components of learning resources can include messages, people, materials, equipment, techniques/ methods, and environments that are used partially or in combination to facilitate the learning process. Furthermore, learning resources can be categorized into two things, namely learning resources that are designed and learning resources that can only be used (Musfiqon, 2012). If we look at the concepts of learning resources, then Dokterswoning can be used as a source of historical learning in schools, in the category Dokterswoning is a learning resource that can be used immediately, the contents of which can be messages (historical facts), materials and places (buildings). Dokterswoning cultural heritage, as well as the environment (historical context in which Dokterswoning becomes a single space in local history in Metro). 
Based on the results of observations on history learning in schools, both in Metro City, Lampung Timur Regency, and Lampung Tengah Regency, it shows that in practice, the use of local sources such as cultural heritage that is both material and intangible has not been used by teachers to teach history to their students. Many things are the cause, including the teacher's lack of knowledge of the knowledge of cultural heritage around them, the teacher's lack of confidence that this cultural heritage can be used in history learning so that teachers still have difficulty integrating or contextualizing local resources in the form of cultural heritage in historical learning. Several previous studies utilize cultural heritage in history learning, both in the form of historical heritage sites, historical memorials (Amboro, 2021; Ariyani \& Huda, 2016; Darmayanti et al., 2018; Guntur et al., 2018; Habsari, 2016; Hartati et al., 2020; Pardi \& Margi, 2013; Wuni et al., 2018), to intangible cultural heritage such as stories of local heroes and various forms of local wisdom (Antara et al., 2017; Effendi, 2019). Based on the results of previous research, it can be emphasized that local cultural heritage, both material and intangible, can be used for historical learning.

\section{RESEARCH METHODS}

This research was conducted using a qualitative approach. This approach seeks to describe and analyze phenomena, events, reality, social activities, attitudes, beliefs, perceptions, thoughts of people both individually and in groups (Sukmadinata, 2007). Inductive techniques are used by observing the Dokterswoning Cultural Heritage building object, then drawing general conclusions supported by some information, so that the data obtained is descriptive.

The data collected included field notes in the form of descriptions of the physical condition, the structure of the place, and other objects around it. Data collection techniques used includes interviews, documentation, and direct observation in the field. Interviews were conducted with informants who knew information about the Dokterswoning Cultural Heritage building and to history teachers, while documentation was carried out by collecting archives, documents, and recording images of the Dokterswoning Cultural Heritage building and also reviewing curriculum documents for historical subjects at schools, and observations were made on the Cultural Heritage building. Dokterwoning is to observe aspects that can be used as a source of historical learning. Qualitative data analysis was carried out using an interactive analysis model as proposed by Huberman, namely, the data analysis process was carried out simultaneously with the data collection process in the field (Sutopo, 2002).

\section{RESULTS AND DISCUSSION \\ History of Dokterswoning Cultural Heritage Building in Metro}

The Dokterswoning Cultural Heritage Building in Metro is one of the historical buildings in Metro City. Dokterswoning is a silent witness to the long history of the development of Metro as an area that was born as the implementation of the Ethical Policy (education, irrigation, migration) of the Dutch East Indies Government in Lampung (Amboro et al., 2018; Kuswono et al., 2020). The implementation of the Ethical Policy in Lampung was carried out in two phases, namely the Experimental Phase (1905-1931) and the Expansion Phase (1932-1941). The implementation of the Ethical Policy which consists of three parts is carried out in an integrated manner, through the transfer of the Javanese population to Lampung which is called the colonization program, the construction of irrigation for agricultural purposes, and education for the natives. In the first phase, several large agricultural colonies were in Gedongtataan and Wonosobo, while in the second phase large agricultural-based colonies were opened in 
Sukadana and Belitang. At that time, Metro was designed as the center or capital of the Sukadana Colonization which had a fairly large area, which is about 55,000 hectares (Pelzer, 1948).

Dokterswoning comes from the Dutch language which means Doctor's House. Dokterswoning is a residential building intended for government doctors who are given the task of providing health services at the Sukadana Colonization Center assisted by other health workers. Dokterswoning was built right behind the controller's house, and not far from the location of the hospital run by Missi or Rooms Katholieke Missie (Amboro \& Bambang, 2020). The Deli Courant newspaper, which was published in April 1939, reported that a person who was appointed as a colonization doctor, namely Mas Soemarno Hadiwinoto, would occupy the doctor's house or Dokterswoning in the Metro. While waiting for a house for him to be completed in Metro. So that temporarily dr. Soemarno lived in Gedong Tataan (Deli_courant, 1939a).

Regarding the development of Dokterswoning, De Indische Courant, and Bataviaasch Nieuwsblad, published in June 1939, many newspapers reported about the development process at the center of the Sukadana Colonization including Dokterswoning. So it can be estimated that the construction of Dokterswoning in the Metro will begin construction between May until June 1939 (Bataviaasch_nieuwsblad, 1939; De_Indische_courant, 1939a). Furthermore, a few months later, many newspapers reported on the development of this Dokterswoning development process until the completion of its construction in February

1940.

(Algemeen_handelsblad_voor_Nederlandsc h-Indië, 1939; De_Indische_courant, 1939b, 1939c; De_Locomotief, 1939; Deli_courant, 1939b;

Het_nieuws_van_den_dag_voor_Nederland sch-Indië, 1939). In March 1940, a photographer who worked for the Dutch East Indies Government in Batavia, namely
Jan van der Kolk, took this photo of Dokterswoning and several other pictures to shoot to make a colonial propaganda film.

Judging from its architectural style, Dokterswoning has a mixed architectural style, namely the Indies style or the New Indies style which is a mix of European styles (classical and neo-classical) and local architectural styles. The Indies style is a new form that was born from the adaptation process to the tropical climate and culture in Indonesia. Metro is an area that was opened and developed by the Dutch East Indies Government, so it will be very easy to find a mix of European and local architecture in buildings and their spatial patterns (Amboro, 2018a, 2018b). So that when viewed from the visible features and the period time of its construction, the Dokterswoning building can be categorized as historical and archaeological remains at the end of the colonial period. Therefore, it can be said that Dokterswoning as a cultural heritage building needs special attention so that its authenticity and preservation are maintained.

\section{The Important Value of Dokterswoning Cultural Heritage Building for Historical Learning Resources}

As a historical building from the Dutch East Indies Colonial Government whose existence still exists, Dokterswoning has some potentials that can be used as a source of historical learning, especially local history. As with several other historic buildings and locations related to the Sukadana Colonization, such as the sluice building in Trimurjo, the former Inlandschbestuur Official House on Jalan Diponegoro Metro (in front of the Metro City Police), to the spatial pattern of the Metro City which was once the capital of the Sukadana Colonization. the central spatial pattern of the capital of the kingdoms in Java, namely the "catur gatra tunggal" (the unity of the four main elements including the center of government, religious center, economic center, and 
center of public activity) and integrated with modern spatial patterns.

The use of various historical buildings, sites, and locations as a resource in learning history can train historical thinking skills and build historical awareness of students through various methods and approaches (Amboro, 2015; Fadli et al., 2020). Historical thinking is an ability developed by historical education through history learning because, in addition to aiming at mastering cognitive knowledge, history learning needs to train students' thinking skills related to history (Black, 2011; Seixas, 2017).

From the perspective of historical education, if the existence of Dokterswoning is used optimally, it can also become a means of learning history for the community or the public (Amboro, 2020; Amboro \& Anindita, 2020). Because the process of learning a person's history does not only stop when he finishes school, but the process of learning history and learning from past experiences will continue to be carried out by an adult human in living his life. Things can be taken into consideration about the need to use Dokterswoning as a source of learning history in schools, including:

Contextual Historical Aspects. The existence of Dokterswoning has a very important historical value, especially for the people around it. The people who live in the ex-colonization area of Sukadana, which are now partially located in three administrative regions (Lampung Tengah Regency, Lampung Timur Regency, and Metro City) have strong historical ties. Metro as the capital of the colonization area was the center of coordination activities for the implementation of Ethical Policy in the Sukadana Colonization. These historical traces can certainly be a clue for the younger generation who are currently studying in school to be able to understand the origins of how the current sheet which is currently running was started. This is a historical potential that must be utilized as a part of local historical knowledge by educators in teaching history through a contextual approach and contextualization process to their students (Amboro, 2019; Barton \& Levstik, 2008; Booth, 2003; Kyvig \& Marty, 2010). Whereas traces of the implementation of Ethical Policies that students learned from their history textbooks (which are currently still dominated by Jawasentris) are also around them. This shows that history is near, and history is part of their life. Using local history and history around students will make it easy for students to find historical significance as part of historical thinking skills that need to be built from history learning (Clark \& Levesque, 2018; Levesque, 2008).

Historical significance is an attempt to find a rationalization that past events are important and relevant to the present, this is also related to contextualization. By finding historical significance, students will get a pragmatic value from history. The history learning that occurs will encourage students to build their perspectives about the environment, and what happened in the past. History will be of value, and independence will be built in history learning (Booth, 2003).

Educators can use various ways to exploit the historical potential of Dokterswoning's existence. In material, educators can package it in the development of local history material that is integrated into national history, considering that the 1905 Ethical Politics learning material is part of the core material of Indonesian National History. Methodologically, educators can use a variety of methods, such as historical investigations (VanSledright, 2011) and tracing and storytelling (Kyvig \& Marty, 2010). Doing learning activities by tracing traces, investigating, and then retelling can be meaningful learning activities for students. This potential can be categorized into learning resources that educators need to design as creatively as possible.

Monument for Keeping Collective Memory. History is written memory or 
human memories (historiography). Memories of events that have occurred in the past, their existence is a prerequisite for the existence of the present. Therefore, teaching history is teaching human memory (Kansteiner, 2017) from generation to generation which has become a collective memory (Glassberg, 1996; Wasino \& Hartatik, 2018). Memories or memories can be lost, destroyed through the process of forgetting and being forgotten, except for memories that are written down, cared for, preserved, and stored. Historical buildings are objects where collective memory is attached and stored, not only buildings, landscapes, areas can also store collective memories (Kyvig \& Marty, 2010).

Dokterswoning is a historical heritage building embedded in its part of the collective memory about the colonization of Sukadana. Its existence is a monument, marker, reminder, evidence of events in the past (Carroll, 2018; Duncan, 2009). Dokterswoning is part of the historical explanation, that health problems are a problem that always haunts the colonists when they are surviving, struggling, and surviving to build a "civilization" from zero. As well as haunting the government at that time because it could threaten the success of its colonization program. Its existence can also be a sign that there are government doctors who have been in charge of providing services to the colonists so that they can stay healthy and can fight the threat of diseases, such as malaria, which at that time can endanger at any time due to the poor quality of environmental sanitation (former forests and swamp). This collective memory then influences the collective identity (Kammen, 1997), especially for those who are descendants of the overseas Javanese, an identity which is then built, for example, Putra Kolonis, Putra Jawa Kelahiran Sumatra (PUJAKESUMA), and other social identities that are built because of the common memory their ancestors. So learning history should come to this point, not just memorizing numbers of years, names and events.
As a monument, Dokterswoning's existence can bring back forgotten history or memories (Carroll, 2018) or reminisce about events that have occurred (Boret \& Shibayama, 2018). This potential must of course be utilized in the learning of local history so that the process of preserving and maintaining collective memory continues and is sustainable for future generations. The current millennial generation did not directly experience the historical events of the colonization, however, it is possible to rebuild collective memory. Social memory in society will never be the same, even if contemporary people will interpret their social memory differently, but that the whole society talks about the event, considers it important, and does not ignore the importance of the memory as its goal (Roosa et al., 2004). Likewise, efforts to build collective memory from predecessors to future generations are needed (Dickerman, 2018; Halbwachs, 1941, 1980). Presenting these memories, and allowing each generation to rebuild their memories and meanings of the past according to their context and era, is the task of learning history.

Apart from having educational and knowledge values, Dokterswoning as a monument also has artistic and recreational values (Anshori et al., 2012; Nas, 1992; Rizqiyah \& Setyawan, 2012). Dokterswoning as a monument, clearly attached to the value of education and knowledge about events that occurred in the past. Its current existence, which can still be found, and is in good condition, certainly has a narrative behind it, why it was built in the past so that it is now there. The value of struggle and adaptive nature can also be learned from the memories of our predecessors, their ancestors as pioneers were moved from the island of Java, away from their homeland and relatives, to build a new civilization on the other side of the land. The artistic value of the Dokterswoning building can also be a track record of architectural development and residential development technology for a 
certain class of society at that time. As well as the recreational value is present when students visit it, witnessing the magnificent historical traces that still exist today in carrying out its function as messengers from the past. Even a recreational function can also be present in the form of exploration of the historical imagination of students, to imagine, to reconstruct their cognitive structures about how situations and conditions in the past (Supriatna, 2019).

\section{Moral Values and Character Values of Dokterswoning Cultural Heritage Buildings and Their Potentials for Learning Resources of History}

The existence of Dokterswoning as a learning resource has character values that can be developed in learning history, especially local history. Character values have always been inherent in history as a moral message from the past for a better life into the future (Peterson, 2017). This value can always be present from every historical event that occurs, be it good or bad events for the Indonesian people. This then makes studying history will make humans wiser, because it always contains values, lessons from historical events that occur. An educator must be able to invite his students to be able to take these values and lessons. Learning from Dokterswoning, several things that can be developed in learning history include:

\section{Orientation to the Future.}

Dokterswoning is one form of implementation of careful planning that has been prepared in advance. Colonization is not a spontaneous, unplanned program. Long before recruiting prospective colonists to be relocated, the Dutch East Indies Government previously carried out an indepth study of the areas where colonists would be placed, including studies of all kinds of potential supporters and potential threats, such as diseases, for example. Reflecting on previous experiences in the First Phase of Colonization (1905), the health problem is one of the serious problems faced, and often causes the failure or development of colonization in an area. Therefore, during this Expansion Phase in the Colonization of Sukadana, the Dutch East Indies Government prepared more thoroughly so that failures and mistakes that had occurred would not be repeated or the possibility of failure could be minimized and prevented. From here students can learn about one thing, namely the need to have a vision for the future and prepare for the future as best as possible, and history teaches that. History does talk about the past, but it is oriented towards the future. And become a single linear line between the past, present, and future.

Equality. Dokterswoning was built as the residence of the first colonization doctor who was given the task of providing health services in the Sukadana Colonization, namely Mas Soemarno Hadinoto. Doctor Soemarno was a doctor who came from an indigenous circle, this shows that the Indonesian nation, which was then called the inlander, could raise its rank and be equal to the Dutch at that time by studying and through education. Even though access to education at that time was still very limited, the Indonesian nation as a nation that was always claimed by the colonial nation was stupid and backward, could prove that the Indonesian nation could progress and be equal to other nations. This can be taught to students, that the threat to become a backward and colonized nation has always existed until now, and that will happen when this nation is again in ignorance. The long journey of the nation's history shows that the struggle with the pen and sharp bamboo are two inseparable sides of a coin. Struggles that rely solely on physicality (which are still regional, the era of the Aceh War, Imam Bondjol, Pangeran Diponegoro, and so on) will find it difficult to repel colonialism, as well as resistance that only relies on pen and diplomacy (the struggle for the period of national movements and political organizations) will be just as difficult. However, the collaboration between the two (the struggle for the Japanese occupation) could produce 
results for independence. This certainly can be a motivation for students to always study hard and become a developed nation in the future.

Concern and Responsibility. The spirit and spirit of Ethical Policy are the enforcement of human values for colonized nations that have provided many benefits to the Kingdom of the Netherlands. Although in practice the Ethical Policy was carried out to benefit the colonialists, the Dutch Indies government's concern for the indigenous had increased. The Dutch East Indies government considered that there was a need for concern for the natives so that their standard of living was increased, and their productivity was also increased and the programs that the government had launched could run well. Dokterswoning was proof of the Dutch Indies Government's attention to the health problems of the colonists, which was one of the keys to the success of the colonization program. Since the beginning of the selection process, prospective colonists in their hometowns have passed the health check stage, as the main requirement so that they can survive, survive in their new place which is so harsh and demands high adaptability and endurance (Levang, 2003; Sjamsu, 1960). Arriving in the land of Sabrang, to ensure the colonists' health was still good and able to survive and develop their new areas, it was necessary to have doctors and medical personnel who took care of their health.
This spirit of caring and responsibility must be conveyed from educators to their students after learning about this Dokterswoning, and internalizing them, and enculturating them in their daily lives.

Reflection. As a source of historical learning, Dokterswoning can be a material for historical reflection. Students can be invited to reflect on what has been learned from the past and what the situation is today. Finding out what has changed and what remains, or about the progress and setbacks that have occurred (Levesque, 2008), determines in which direction the future will be built. Building collective memory in history learning will also lead students to reflect on the human nature of remembering and forgetting (Barton \& Levstik, 2008). About what to remember from the past to serve as motivation and guidance, and what to forget and simply leave behind, without needing to carry it over to the present and future.

Historical mapping of Dokterswoning cultural heritage buildings as a source of historical learning based on Core Competencies (Kompetensi Inti/KI) and Basic Competencies (Kompetensi Dasar/KD) in History Subjects High School Level based on national curriculum (Kurikulum 2013) (Permendikbud RI Nomor 37, 2018):

Table 1. Mapping Dokterswoning into KI and KD in History subjects

Historical Learning Resources based on Local Cultural Heritage

A. Background and History of the Dokterswoning Cultural Heritage Building

B. Physical Form of Dokterswoning Cultural Heritage Building (Building Style, Architecture, Layout, Technology)

Development in KI and KD
Class X
Core Competencies (KI)
3. Understand, apply, and analyze factual, conceptual, procedural knowledge based on curiosity about science, technology, arts,
culture, and humanities with insight into humanity, nationality, statehood, and civilization related to phenomena and events, and
apply procedural knowledge to specific fields of study according to their talents and interests to solve problems.
4. Processing, reasoning, and presenting in the realm of the concrete and the abstract realm related to the development of what they
learn in school independently, and being able to use methods according to scientific principles.
Basic Competencies (KD)
3.1 Understanding and applying the concepts of chronological, diachronic, synchronic, space and time thinking in history.
3.2 Understand the concept of change and continuity in history
4.1 Presenting information about the relationship between the concepts of chronological thinking, diachronic, synchronic, space,
and time in historical events in the form of writing or other forms.
4.2 Applying the concept of change and sustainability in assessing historical events.


Kian Amboro et.al. Identifications of character values from the history of dokterswoning cultural heritage buildings and potentials for learning history resources in schools.

\begin{tabular}{|l|} 
Table 1 Continued... \\
Class XI \\
Core Competencies (KI) \\
3. Understand, apply, and analyze factual, conceptual, procedural knowledge based on curiosity about science, technology, arts, \\
culture, and humanities with insight into humanity, nationality, statehood, and civilization related to phenomena and events, and \\
apply procedural knowledge to specific fields of study according to their talents and interests to solve problems. \\
4. Processing, reasoning, and presenting in the realm of the concrete and the abstract realm related to the development of what they \\
learn in school independently, and being able to use methods according to scientific principles. \\
Basic Competencies (KD) \\
3.3 To analyze the political, cultural, social, economic, and educational impacts of the European colonial period (Portuguese, \\
Spanish, Dutch, British) on the life of the Indonesian people today. \\
4.3 Reasoning about the political, cultural, social, economic, and educational impacts of the European colonial period (Portuguese, \\
Spanish, Dutch, British) on the life of the Indonesian people today and presenting them in the form of historical stories.
\end{tabular}

Mapping of character values that can be developed following the character values as stated in the Guidelines for the
Development of National Character and Cultural Education for Schools (Pusat.Pengembangan.Kurikulum, 2010):

Table 2. Mapping of Developable Character Values

\begin{tabular}{|c|l|c|c|}
\hline \multirow{2}{*}{ No } & \multicolumn{1}{|c|}{ Historical Learning Resources } & \multicolumn{2}{c|}{ Values Identification } \\
\cline { 3 - 4 } 1 & $\begin{array}{l}\text { Background and History of the Dokterswoning } \\
\text { Cultural Heritage Building }\end{array}$ & $\begin{array}{l}\text { Future Orientation, Equality, } \\
\text { Concern, and Responsibility, } \\
\text { Reflection }\end{array}$ & $\begin{array}{c}\text { Discipline, Hard Work, Curiosity, Love to } \\
\text { Read, Care for the Environment, Care for } \\
\text { Social, Responsibility }\end{array}$ \\
\hline 2 & $\begin{array}{l}\text { Physical Form of Dokterswoning Cultural } \\
\text { Heritage Building (Building Style, Architecture, } \\
\text { Layout, Technology) }\end{array}$ & Adaptation, Reflection & $\begin{array}{c}\text { Hard Work, Creative, Curiosity, Care for the } \\
\text { Environment }\end{array}$ \\
\hline
\end{tabular}

*Based on 18 National Character Values in the Guidelines for the Development of National Culture and Character Education for Schools (Pusat.Pengembangan.Kurikulum, 2010).

Based on this mapping, later the teacher can develop it into a lesson plan with a contextual learning approach. Thus the potential learning resources that exist around students can be utilized in historical learning, whether in the form of local history, local wisdom, cultural heritage that is material such as buildings, objects, sites, or cultural heritage that is intangible such as folklore, myths, and legends.

\section{CONCLUSION AND SUGGESTION Conclusion}

Dokterswoning cultural heritage building is evidence of historical heritage in Metro City. Its existence is evidence of Metro's long history as a region and a city that was born from the implementation of the Ethical Policy of the Dutch East Indies Colonial Government in Lampung. Dokterswoning from the historical aspect and the architectural style of the building has the potential to be utilized and developed into a source of historical learning based on local knowledge. Its importance is in contextual historical aspects and as a monument to the guardian of collective memory.

Several moral values can also be developed: Orientation to the Future, Equality, Concern, and Responsibility, and Reflection. Meanwhile, based on the Guidelines for the Development of Cultural Education and National Character for Schools which contain 18 (eighteen) national character values, several character values can be identified, including Discipline, Hard Work, Curiosity, Love to Read, Care for the Environment, Social Care, Responsibility, and Creative.

\section{Suggestion}

1. Schools need to participate in introducing and maximizing the potentials around students in the contextual learning process. The history of Dokterswoning can be a part of knowledge that can be taught in schools, especially at the high school level. The history of the Dokterswoning cultural heritage building is also rich in character 
values which reinforce its urgency as a source of historical learning.

2. Local history is not explicitly listed in the national curriculum or Kurikulum 2013, either in Social Sciences or History subjects. However, the current national curriculum provides an opportunity for teachers to explore local history and local potentials to be used as a source of historical learning. So that teachers need to innovate through various kinds of approaches, strategies, models, techniques, and creative learning tactics. Dokterswoning can be taught in a hidden curriculum or it can also be present in the form of enrichment.

\section{ACKNOWLEDGEMENT}

Thank you for the many institutions that have collaborated in carrying out this joint research, namely the Metro City Cultural Heritage Council, the History Education Study Program of the University of Muhammadiyah Metro, SMA Negeri 1 Lampung Timur, the Activist of Historical, Archives, and Cultural Heritage (ARSENIK), and the Activist of Trimoerdjo Heritage.

\section{Conflict of Interest: None}

\section{Source of Funding: None}

\section{REFERENCES}

1. Algemeen handelsblad voor Nederlandsch -Indië. (1939, November). De Kolonisatie Soekadana: Wegen en Woningen worden Gebouwd. Algemeen Handelsblad Voor Nederlandsch-Indië.

2. Amboro, K. (2015). Membangun Kesadaran Berawal Dari Pemahaman; Relasi Pemahaman Sejarah Dengan Kesadaran Sejarah Mahasiswa Program Studi Pendidikan Sejarah Fkip Universitas Muhammadiyah Metro. Historia: Jurnal Program Studi Pendidikan Sejarah, 3(2), 109. https://doi.org/10.24127/hj.v3i2.150

3. Amboro, K. (2018a). Menemukan Jejak Arsitektur Indis di Metro. Rilis.Id.
http://m.lampung.rilis.id/Menemukan-JejakArsitektur-Indis-di-Metro.html

4. Amboro, K. (2018b). Mengamati Metro dari Atas dan Masa Lalu. Rilis.Id. http://m.lampung.rilis.id/Mengamati-Metrodari-Atas-dan-Masa-Lalu.html

5. Amboro, K. (2019). Kontekstualisasi Pandemi Covid-19 dalam Pembelajaran Sejarah. Yupa: Historical Studies Journal, 3(2), 90-106. https://doi.org/10.30872/yupa.v3i2.203

6. Amboro, K. (2020). Sejarah Publik dan Pendidikan Sejarah Bagi Masyarakat. Jurnal Historis: Jurnal Kajian, Penelitian \& Pengembangan Pendidikan Sejarah, 5(1), 29-40.

https://doi.org/https://doi.org/10.31764/histo ris.v5i1.2420

7. Amboro, K. (2021). Bendung Argoguruh 1935 dan Potensinya sebagai Sumber Pembelajaran Sejarah di Lampung. MUKADIMAH: Jurnal Pendidikan, Sejarah, Dan Ilmu-Ilmu Sosial, 5(1), 100110.

8. Amboro, K., \& Anindita, I. P. (2020). Urgensi Pemanfaatan Rumah Dokter (dokterswoning) sebagai Sumber Pembelajaran Sejarah di Sekolah. In Tim Ahli Cagar Budaya (TACB) Kota Metro (Ed.), Dokterswoning: Sejarah Rumah Dokter Kota Metro (pp. 55-69). AURA Publisher.

9. Amboro, K., \& Bambang, S. (2020). Sekilas Sejarah Rumah Dokter Metro. In Tim Ahli Cagar Budaya (TACB) Kota Metro (Ed.), Dokterswoning: Sejarah Rumah Dokter Kota Metro (pp. 20-28). AURA Publisher.

10. Amboro, K., Syahidah, F., Hartati, U., \& Kuswono. (2018). Album Metro Tempo Dulu Era Kolonisasi 1932-1940an. Dinas Perpustakaan dan Kearsipan Kota Metro.

11. Anshori, S. A., Yusiana, L. S., \& Utami, N. W. F. (2012). Perencanaan Lanskap Monumen Pahlawan Perang Kemerdekaan Republik Indonesia 1945, Taman Mumbul, Nusa Dua, Bali. E-Jurnal Agroteknologi Tropika, 1(2).

12. Antara, I. M. A. E., Atmadja, N. B., \& Sendratari, L. P. (2017). Peranan Mayor I Gusti Wayan Debes Dalam Puputan Margarana Tabanan , Bali ( Identifikasi Nilai-Nilai Kepahlawanan Dan Potensinya Sebagai Sumber Belajar Peranan Mayor I Gusti Wayan Debes Dalam Puputan Margarana Tabanan , Bali ( Identifikasi 
Nilai-Nilai Kepa. Jurnal Widya Winayata, $5(3)$.

https://doi.org/http://dx.doi.org/10.23887/jjp s.v5i3.4909

13. Ariyani, R. W., \& Huda, K. (2016). Situs Masjid Agung Sewulan (Sejarah dan Potensinya Sebagai Sumber Belajar Sejarah SMP/MTsN). Agastya: Jurnal Sejarah Dan Pembelajarannya, 6(02), 97-111. https://doi.org/10.25273/ajsp.v6i02.1042

14. Barton, K. C., \& Levstik, L. S. (2008). Teaching History for the Common Good. Lawrence Erlbaum Associates Publishers.

15. Bataviaasch_nieuwsblad. (1939, June). Nieuws uit de Lampongs. Bataviaasch Nieuwsblad.

16. Black, L. (2011). History Teaching Today: Approaches and Methods. The European Commision Liasion Office.

17. Booth, A. (2003). Teaching History at University; Enhancing Learning and Understanding. Routledge.

18. Boret, S. P., \& Shibayama, A. (2018). The roles of monuments for the dead during the aftermath of the Great East Japan Earthquake. International Journal of Disaster Risk Reduction, 29(March), 55-62. https://doi.org/10.1016/j.ijdrr.2017.09.021

19. Carroll, B. (2018). Monumental Discord: Savannah's Remembering (and Forgetting) of Its Enslaved. Visual Communication Quarterly, 25(3), 156-167. https://doi.org/10.1080/15551393.2018.149 1736

20. Clark, P., \& Levesque, S. (2018). Historical Thinking: Definitions and Educational Applications. In S. A. Metzger \& L. M. Harris (Eds.), The Willey International Handbook of History Teaching and Learning (pp. 119-148). Willey-Blackwell.

21. Darmayanti, W. D., Mudana, I. W., \& Margi, K. (2018). Identifikasi Potensi Taman Soekasada Ujung, di Desa Tumbu, Kabupaten Karangasem, Bali sebagai Sumber Belajar Sejarah Lokal di SMA. Jurnal Widya Winayata, 6(1). https://doi.org/http://dx.doi.org/10.23887/jjp s.v6i1.4277

22. De_Indische_courant. (1939a). Uit de Lampongs: De doorgaande verbinding van Tandjongkarang naar Palembang. - De voltooiing van twee groote betonboogbruggen. - Ook nog een geregelde autobusverbinding. De Indische Courant.
23. De_Indische_courant. (1939b, August). De Javanen-Kolonisaties in de Lampongs. De Indische Courant, 286.

24. De_Indische_courant. (1939c, November). De Situatie in Soekadana. De Indische Courant.

25. De_Locomotief. (1939, November). De Situatie in Soekadana. De Locomotief.

26. Deli_courant. (1939a, April). KolonisatieDokter in de Lampongs. Deli Courant, $3 e$.

27. Deli_courant. (1939b, September). De Kolonisaties in de Lampongs. Deli Courant.

28. Dickerman, L. (2018). Monumental Propaganda. October, 165, 178-191. https://doi.org/10.1162/octo_a_00328

29. Duncan, C. R. (2009). Monuments and martyrdom Memorializing the dead in postconflict North Maluku. 165(4), 429-458.

30. Effendi, H. (2019). Kontekstualisasi Fungsi Bagas Godang dan Sopo Godang Sebagai Sumber Pembelajaran Sejarah Lokal. Diakronika, $18(2), \quad 19$. https://doi.org/10.24036/diakronika/vol18iss $2 / 66$

31. Fadli, M. R., Sudrajat, A., Zulkarnain, Z., Aman, A., Setiawan, R., \& Amboro, K. (2020). The Effectiveness of E-Module Learning History Inquiry Model to Grow Student Historical Thinking Skills Material Event Proclamation of Independence. International Journal of Advanced Science and Technology, 29(08), 1288-1295. http://sersc.org/journals/index.php/IJAST/ar ticle/view/20146

32. Glassberg, D. (1996). Public history and the study of memory. Public Historian, 18(2), 7-23. https://doi.org/10.2307/3377910

33. Guntur, A., Syukur, A., \& Umasih. (2018). Kraton Buton Sebagai Sumber Sejarah Lokal Dalam Pembelajaran Sejarah. Jurnal Pendidikan Sejarah, 7(1), 85-98. https://doi.org/10.21009/JPS.071.06

34. Habsari, N. T. (2016). Situs Ngurawan: Sejarah dan Potensinya sebagai Sumber Belajar Sejarah Lokal. Agastya: Jurnal Sejarah Dan Pembelajarannya, 6(1), 58-64. https://doi.org/http://doi.org/10.25273/ajsp.v 6i01.881

35. Halbwachs, M. (1941). Space and the collective memory. The Collective Memory, $1-15$.

36. Halbwachs, M. (1980). The Collective Memory. Harper and Row.

37. Hartati, U., Sumiyatun, S., \& Prastyo, A. B. (2020). Cagar Budaya Sebagai Sumber 
Belajar Sejarah Lokal. Diakronika, 20(2), 143.

https://doi.org/10.24036/diakronika/vol20iss $2 / 155$

38. Hasan, S. H. (2012). Pendidikan Sejarah Untuk Memperkuat Pendidikan Karakter. Paramita: Historical Studies Journal, 22(1). https://doi.org/10.15294/paramita.v22i1.187 5

39. Het_nieuws_van_den_dag_voor_Nederland sch-Indië. (1939, November). De Situatie in Soekadana. Het Nieuws van Den Dag Voor Nederlandsch-Indië.

40. Kammen, M. (1997). Public History and the Uses of Memory. The Public Historian, 19(2), 49-52. https://doi.org/10.2307/3379141

41. Kansteiner, W. (2017). Film, the Past, and a Didactic Dead End: From Teaching History to Teaching Memory. In M. Carretero, S. Berger, \& M. Grever (Eds.), Palgrave Handbook of Research in Historical Culture and Education (pp. 169-190). Palgrave Macmillan UK.

42. Permendikbud RI Nomor 37, 368 (2018).

43. Kuswono, Hartati, U., Amboro, K., Mujiyati, N., Immawati, F. L., Tantri, A. D., \& Wijaya, A. R. (2020). Metro Tempo Dulu: Sejarah Kota Metro Era Kolonisasi 1935-1942 (B. Hidayat \& U. Hartati (eds.); 1st ed.). LADUNY.

44. Kyvig, D. E., \& Marty, M. A. (2010). Nearby History: Exploring The Past Around You (Third Ed.). Altamira Press.

45. Levang, P. (2003). Ayo ke Tanah Sabrang; Transmigrasi di Indonesia. Kepustakaan Populer Gramedia.

46. Levesque, S. (2008). Thinking Historically: Educating Students for the Twenty-First Century. University of Toronto Press.

47. Musfiqon, H. M. (2012). Pengembangan Media dan Sumber Pembelajaran. Prestasi Pustaka.

48. Nas, P. J. M. (1992). Jakarta, City Full of Symbols: An Essay in Symbolic Ecology. Journal of Social Issues in Southeast Asia, $7(2)$.

49. Pardi, I. W., \& Margi, I. K. (2013). Eksistensi Punden Berundak di Pura Candi Desa Pakraman Selulung, Kintamani, Bangli (Kajian tentang Sejarah dan Potensinya sebagai Sumber Belajar Sejarah). Jurnal Widya Winayata, 1(3). https://doi.org/http://dx.doi.org/10.23887/jjp s.v1i3.1020
50. Pelzer, K. J. (1948). Pioneer Settlement in the Asiatic Tropics: Studies in Land Utilization and Agricultural Colonization in Southeastern Asia. American Geographical Society.

51. Peterson, A. (2017). Moral education, character education and history. In I. Davies (Ed.), Debates in History Education (pp. 191-201). Routledge.

52. Pusat.Pengembangan.Kurikulum. (2010). Pedoman Pengembangan Pendidikan Budaya dan Karakter Bangsa. Kementerian Pendidikan Nasional.

53. Rizqiyah, F., \& Setyawan, W. (2012). Aplikasi Monumentalisme dalam Perancangan Museum Gempa Yogyakarta sebagai Upaya Membangkitkan Kesadaran Masyarakat akan Ketanggapan Terhadap Gempa Bumi di Yogyakarta. Jurnal Sains Dan Seni Its, 1(1).

54. Rohani, A. (1997). Media Instruksional Edukatif. Rineka Cipta.

55. Roosa, J., Ratih, A., \& Farid, H. (2004). Tahun yang tidak pernah berakhir. ELSAM.

56. Seixas, P. (2017). Historical Consciousness and Historical Thinking. In M. Carretero, S. Berger, \& M. Grever (Eds.), Palgrave Handbook of Research in Historical Culture and Education (pp. 59-72). Palgrave Macmillan UK. https://doi.org/10.1057/9781-137-52908-4_3

57. Sjamsu, M. A. (1960). Dari Kolonisasi ke Transmigrasi 1905-1955. Djambatan.

58. Sukmadinata, N. S. (2007). Metode Penelitian Pendidikan. Remaja Rosdakarya.

59. Supriatna, N. (2019). Pengembangan Kreativitas Imajinatif Abad Ke-21 dalam Pembelajaran Sejarah. Historia: Jurnal Pendidik Dan Peneliti Sejarah, 2(2), 73-82. https://doi.org/10.17509/historia.v2i2.16629

60. Sutopo, H. B. (2002). Metode Penelitian Kualitatif. UNS Press.

61. UNESCO. (n.d.). Definition of the cultural heritage. United Nations Educational, Scientific, and Cultural Organizations. Retrieved May 15, 2021, from www.unesco.og

62. UU RI No 11. (2010). Undang-Undang Republik Indonesia Nomor 11 Tahun 2010 tentang Cagar Budaya. Direktorat Pelestarian Cagar Budaya dan Permuseuman.

63. VanSledright, B. A. (2011). The Challenge of Rethinking History Education: On Practices, Theories, and Policy. Routledge. 
Kian Amboro et.al. Identifications of character values from the history of dokterswoning cultural heritage buildings and potentials for learning history resources in schools.

64. Wasino, \& Hartatik, E. S. (2018). Metode Penelitian Sejarah: Dari Riset hingga Penulisan. Magnum Pustaka Utama.

65. Wuni, I. A. K. N., Sendratari, L. P., \& Margi, I. K. (2018). Gereja Pniel di Desa Blimbingsari, Jembrana, Bali (Sejarah Pendirian Dan Potensinya Sebagai Sumber Belajar Sejarah). Jurnal Widya Winayata, 6(1), 12. http://ejournal.undiksha.ac.id/index.php/JJP

How to cite this article: Amboro K, Setiawati E, Setiawan A et.al. Identifications of character values from the history of dokterswoning cultural heritage buildings and potentials for learning history resources in schools. International Journal of Research and Review. 2021; 8(5): 273-285. DOI: https://doi.org/ 10.52403/ijrr.20210535 